\title{
Understanding Impacts of Cultural Tourism on Sustainability of Rural Architecture in Three Villages of Bursa*
}

\author{
Sermin Çakıcı Alp*, Elif Acar Bilgin
}

\author{
Keywords: \\ Tourism \\ Sustainability \\ Rural architecture \\ Bursa
}

\author{
Article History: \\ Submitted:01.08.2019 \\ Accepted:28.11.2019
}

\begin{abstract}
This paper aims to describe the consequences of cultural tourism for sustainability of rural architectural heritage of three villages, named as Misi, Gölyazl, and Tirilye, in Bursa. For this purpose, natural and architectural values in each of these three villages are described in detail, while mentioning the importance of a sustainable rural development plan, which would provide qualified advertisement and prevent destruction of cultural tourism. Before explaining the method of the study, a theoretical framework, including both concepts and legal aspects about the issues of cultural tourism and rural heritage, is given in detail. Afterwards, values and potentials of selected case studies are given while also evaluating the problems and threats on their sustainability. It concludes with discussion on findings that includes results and recommendations, in order to improve the values and potentials of a historic village against touristic threats and problems. Hence, this study is essential as investigating the challenges of tourism in conservation of rural areas in Bursa, known as one of the UNESCO World Heritage Sites (WHS) in Turkey, while explaining the benefits of sustainability in rural development together with increasing interest and public awareness in related architectural and natural heritage.
\end{abstract}

\section{Doi: https://doi.org/10.31822/jomat.599612}

\section{Introduction}

Cultural heritage, including historic landscape and built environment, symbolizes irreplaceable sources of life and inspiration. However, it is still difficult to continue authenticity of existing artefactual heritage elements while presenting them to the new generation. Touristic activities should prevent damage and contribute to raise awareness in sustainability of cultural heritage sites. Besides, requirement for new spaces in accommodation and gastronomic needs of cultural tourism might result in climate change, waste production and pollution, which are major environmental problems need to be concerned for sustainability.
Cultural tourism means voluntary mobility of travellers, tourists, and visitors with the motivation of experiencing tangible and intangible cultural heritage and developing opportunities for self-questioning, self-learning, and selfdevelopment (EU Sustainable Tourism Guidelines, 2009). This sector also needs people concentrating on philosophical, metaphysical, and well-educated learning opportunities other than focusing on body related consumptions such as sportive activities.

The increasing awareness of tourists, gathering information for higher quality travels, has created a desire to get to know the culture, lifestyle and traditions of the hosting places, mostly the

\begin{tabular}{cl}
\hline${ }^{*}$ Corresponding Author & \\
\hline Sermin Çakıcı Alp: & Asst. Prof., Bolu Abant İzet Baysal University Faculty Of Architecture, Email: sermincakici@ gmail.com, Orcid \\
& Id: 0000-0001-9364-5024
\end{tabular}

Elif Acar Bilgin: $\quad$ Research Assistant, Bursa Uludă̆ University Graduate School Of Natural \& Applied Sciences, Email: elifacarb@gmail.com, Orcid Id: 0000-0001-9589-9757

\section{(i) (6) $\fallingdotseq$}


historical villages. Rural tourism ${ }^{1}$ is recently popular among the researchers for energy efficiency and ecological sustainability (Zhang et al. 2006; Aslam et al. 2015; Lane et al. 2015). Since mass tourism results in environmental degradation in villages, rural tourism is an alternative for gathering benefits for their socioeconomic and infrastructural development. In addition to dairy farming and small scale village industries, it concerns conservation and continuation of cultural heritage and landscapes in villages.

According to the study on the effects of cultural tourism on sustainability of rural heritage ${ }^{2}$ (Kocaman et al. 2014), the touristic events, occuring within historical built environment of the villages, influence public interest and awareness into this heritage, whereas mostly causing transformation and destruction in its authentic character. Hence, it is essential to find out what kind of architectural features are used to improve cultural tourism in rural settlements. The current studies on reclycling of local construction techniques and materials used in vernacular architecture also reveals passive design principles for sustainable rural development (Wahid 2012; Sharma et al. 2013; Fernandes et al. 2014; Davardoust et al. 2019).

It is popular to study on the contribution of rural tourism into sustainable development of historic villages in Turkey by the researchers (Boz et al. 2014; Baysal et al. 2016; Gürdoğan et al. 2016), while explaining its potential and values to be conserved against touristic deformations. Meanwhile, its conceptual approach is defined in detail (Soykan 2003; Babayev 2016), whereas the public and private sectors equate it within the concept of ecotourism together with tableland, hunting, bird watching, and adventure tourism. On the other hand, the importance of public awareness in conservation of rural heritage in various villages of Turkey, such as Beypazarı (Ankara), Göynük (Bolu), and Oltu (Erzurum) is also mentioned by the researchers (Uslu et al. 2006; Denk et al. 2016; Öter et al. 2017; Şengül et al. 2018); as investing the effects of cultural tourism.
In addition to positive effects, the touristic activites in rural areas can cause transformation in social and physical features of the villages. For instance, relocation of local communities from their traditional settlements is a negative socio-cultural impact of tourism, since forcing the community to leave their neighbourhood, which is defined as rural gentrification (Dinçer et al. 2005). That kind of social change results in displacement of communities, disappearance of cultural practices, and subsequent loss of identity of historic rural areas, while also causing rising rents, transport conflicts and traffic congestion (ICOMOS International Committee on Historic Towns and Villages, 2011).

The houses in Doganbey Village, which is located in the Aegean region, are given as example while being abandoned after 1955 earthquake. The local people settled in a new village named as New Doganbey and the old village was re-discovered by a group of people from Istanbul in late 1990s. Consequently, the historical dwellings have been sold to new investors to be restored, despite of social struggle on preservation of their citizen rights. As another example, the local people of Alaçatı, known as a seaside town of Izmir in Turkey, have sold their houses and forced to live in social houses built away from the town center (Tezcan 2010).

Uncontrolled invasion of tourists results in rapid population increase, especially in summer times, which causes economic instability and loss of authentic country lifestyle in historical villages. Increasing demand on tourism sector mostly results in improper repairs and restorations in and outside of historic dwellings, due to permanent changes required in their traditional architectural features. Besides, many hotels and restaurants were built due to domestic needs of visitors, whereas the villages might lose unique natural beauty of their rural pattern.

Cumalıkızık, which is one of $\mathrm{UNESCO}^{3}$ WHS in Bursa, was studied to understand its use as cultural landscape heritage for cultural tourism, by using SWOT and TOWS analysis in evaluation process (Pirselimoğlu Batman et al. 2019). The

\footnotetext{
${ }^{1}$ Cultural Heritage Site refers to a place, locality, natural landscape, settlement area, architectural complex, archaeological site, or standing structure that is recognized and often legally protected as a place of historical and cultural significance (ICOMOS, 2008).

${ }^{2}$ Rural tourism concerns presentation of natural sources together with historic built-environment to the tourists visiting the villages, while its definition has been enlarged by current national and international regulations and approaches (Babayev, 2016).

“.... Rural heritage, forming the rural identity, was defined in very narrow terms. It was considered to consist of buildings associated with agricultural activity, and particularly with "minor rural heritage" such as wash-houses, mills or chapels. Planners now assign a wider definition to heritage, which is considered to include all the tangible or intangible elements that demonstrate the particular relationship that a human community has established with a territory over time..." (European Rural Heritage Observation Guide 2003)
} 
works done during both nomination and acceptance process of this village, as a traditional rural settlement to be conserved by UNESCO, can be accepted as a starting point of perception and revitalization of local culture in Turkey. Moreover, its rural architectural heritage was researched within the concept of cultural tourism (Gürer 2003; Çetin 2010), while traditional structure and character of the dwellings forming its rural identity was evaluated in terms of ecological and sociocultural sustainability (Beceren Öztürk et al. 2010; Özorhon et al. 2014).

In addition to various types of studies on rehabilitation and management of Cumalıkızık, there is still a gap in researches on conservation and sustainable development of rural architectural heritage in other villages of Bursa. For instance, Güney and Göller (2016) works on the approach of local people into sustainable rural development and tourism activities in Misi, while Karacaoğlu et al. (2016) finds out benefits and costs of community based tourism proposed for rural development of this small village. On the other hand, outdoor recreational values ${ }^{4}$ and potentials of Gölyazı village was evaluated (Çelik et al. 2016), and the tourism possibilities in Tirilye village were described (Ertürk 2009) in order to solve migration and employment problems and to arrange for rural development strategies. Although there exist such kind of researches in changes of social values in rural identity of these villages, there is still a gap to understand physical changes of their traditional architectural character as a result of cultural tourism.

Therefore, this study is unique as defining the impacts and results of touristic activities on rural architectural heritage in three villages named as Misi, Tirilye, and Gölyazı, in Bursa. After explaning conceptual and juristical approaches on this issue, the values and potentials of these three villages, selected as the case studies, are given together with the problems and threats on their sustainability in rural development. The paper concludes with recommendations defining what can be done to conserve and to reuse the related rural architectural heritage while responding to demands of cultural tourism.

\section{Theoretical Framework}

Culture has a crucial role in keeping sustainability of a society, together with ecological, economic and social dimensions required for sustainable development ${ }^{5}$. The built environment in a settlement can be accepted as a form of material culture of the community, and derives its meaning from the 'cognitive-cultural system', which is formed by customs, rituals and alike. Menawhile, 'cultural schemas' (Uysal Ürey, 2019: 87-88) could help to understand interpretation and production of architecture' in order to explain the meaningful relationship between the built environment and the users, which is also important for cultural sustainability ${ }^{6}$.

Architecture has a responsibility to manifest shared values publicly in material form and to provide a cultural communication within the society. The architectural type links the act of perceiving and categorization with the act of recreating and designing on the basis of culture (Robinson, 1989: 256). It has a cognitive role in the formation of cultural sustainability, since it both carries the seeds of the culture within the artefact and transfers them to continue existence of the culture through time. This makes the architectural heritage $^{7}$ to allow the modifying of existing cultural values by means of architecture (Robinson, 1989: 273).

The conservation and reuse of existing built environment in rural areas has become essential to understand continuity of cultural heritage while investigating the condition and potential of rural architectural heritage. This issue was firstly mentioned by the regulations of Venice Charter, accepted in $1964^{8}$. In this declaration, rural areas were also accepted as cultural heritage to be conserved, at first. After a decade, the concept of 'integration' was added into conservation issue of both urban and rural areas, firstly in the

\footnotetext{
${ }^{4}$ The flora together with climatic value and simplicity are recreational values and potentials for rural tourism (Çelik et al. 2016: 34 ).

${ }^{5}$ Sustainable development was firstly defined in 'Brundtland Report' (1987), prepared by the World Commission on Environment and Development (WCED), in which a balanced distribution of touristic benefits between different regions and social layers was also proposed (WCED, 2019).

${ }^{6}$ The concept of cultural sustainability itself was first brought up in 1995 by the World Commission on Culture and Development (WCCD) and was defined as the "inter and intra generational access to cultural resources" (WCCD, 1995), which also concerns the preservation of cultural values, ideas, practices, artefacts and heritage in unity (Uysal Ürey, 2019:85)

${ }^{7}$ The architectural heritage, forming the traditional structure of urban and rural areas, is accepted as not only the interest of contemporary lifestyle but also the documentary of social history identifying a community.

${ }^{8}$ International Charter for the Conservation and Restoration of Monuments and Sites (Venice Charter 1964); "Article 1. The concept of a historic monument embraces not only the single architectural work but also the urban or rural setting in which is found the evidence of a particular civilization, a significant development or a historic event."
} 
Amsterdam Declaration ${ }^{9}$ in $1975^{10}$. In the following years, the dynamic reaction between tourism and cultural heritage has become the major issue, in the Charter of International Cultural Tourism, by ICOMOS $^{11}$ (1999), which resulted in several international scientific commissions that are concerned with the conservation of historic rural areas. Meanwhile, the negative effects of tourism on environmental landscape and cultural heritage were discussed and suggested to be minimized, with the approval of 'Ethical Principles of Cultural Tourism ${ }^{12}$ '.

The concept of tourism is based on environment, comprising all of the natural, cultural and visual reserves (Bulut et al., 2008:13). Cultural reserves refer to the historic monumental structures together with çivil architectural samples, historical urban tissues, archaeological sites, cultures and folklores identifying the area. Since mass tourism results in environmental degradation in villages, cultural tourism is an alternative for gathering benefits for their socio-economic and infrastructural development. The alternative tourism is a tool for sustainable rural development by improving natural values and promoting ecotourism activities. This form of tourism can preserve authenticity of rural heritage that haven't faced with deterioration yet, while supporting ethics and ecological perspectives (Butler et al. 1992; Yu et al. 1997; Wood 2001; Liu, 2006). More importantly, it contributes to economical development of villages within the context of rural planning efforts.

In relation with both international and national legislations, the collective study of personal and institutional attempts are essential for conservation and sustainability of cultural heritage in rural areas. Especially, the expos and festivals, which are organized under the leadership of major institutions and NGOs, aid to introduce rural areas to the citizens while the villagers gain economical profit from tourism. For instance, the
Institution of Rural Tourism ${ }^{13}$ have organized symposiums, workshops and AB Projects, interesting in sustainability of social values of the villages in Turkey, while engaging the public into this issue.

Touristic activities, which started to occur in Turkey since the beginning of 1970 s, have caused transformation in spatial character of rural architecture, instead of Historic Artefacts Act (no:1710 Act) ${ }^{14}$, approved in 1973. Following the 1982 Constitution, it has become hard to prevent the loss of local identity and authenticity against physical and social change in historic villages of Turkey due to the expression of "...enough only conserving sufficient number of monuments..." recorded ${ }^{15}$ Afterwards, the approval of "the Law for Conservation of Cultural and Natural Properties (no: 2863 Act)' in $1983^{16}$ has led to the improvement of tourism whereas disregarding preservation of whole vernacular architecture in villages,

ICOMOS Turkey National Committee prepared 'The Conservation of Cultural Heritage Declaration' in 2013, in which rural landscape is defined as an open-air museum displaying the design and construction technique of the local buildings as well as the composition of their layout with roads, squares and agricultural lands. Moreover, the roles and policies of stakeholders are also emphasized to distribute the actors that have role in taking decisions and making implementations in conservation and continuation of rural architectural heritage. Meanwhile, National Rural Development Strategy ${ }^{17}$, in which different types of heritage in rural areas are defined, makes the local sources sustain while improving the quality of rural residents in accordance with the urban ones.

\section{Method}

Social studies on sustainability of rural heritage are adequate to understand contribution of

\footnotetext{
${ }^{9}$ The Declaration of Amsterdam, Congress on the European Architectural Heritage, 21-25 October 1975; “...Integrated conservation involves the responsibility of local authorities and calls for citizens'..."

${ }_{10}$ The Declaration of Amsterdam, “... Article b. The architectural heritage includes not only individual buildings of exceptional quality and their surroundings, but also all areas of towns or villages of historic or cultural interest... Article d. Architectural conservation must be considered, not as a marginal issue, but as a major objective of town and country planning..."

${ }^{11}$ ICOMOS (International Council on Monuments and Sites) is a global non-governmental organization associated with UNESCO. It is founded in 1964 in Warsaw and works for the conservation and protection of cultural heritage places ((http://www.icomos.org.tr/?Sayfa=Icerik\&ayrinti=Icomos\&dil=en) Last access: 03.07.2017).

12 These principles were prepared by World Touristic Organization (WTO) in 1999.

${ }^{13}$ http://www.kirsalturizm.com/

${ }^{14}$ https://www.tbmm.gov.tr/tutanaklar/KANUNLAR_KARARLAR/kanuntbmmc056/kanuntbmmc056/kanuntbmmc05601710.pdf (Last access: 30.05.2017)

15 The Law for the Conservation of Cultural and Natural Properties (no: 2863, approval date: 21/7/1983) part 2, Article 7.

${ }^{16}$ http://www.mevzuat.gov.tr/MevzuatMetin/1.5.2863.pdf (last accessed: 02.07.2017).

${ }^{17}$ The Turkish State Planning Organization prepared The National Rural Development Strategy considering Long Term Development Strategy for period in between 2001 2023 (mevzuat.dpt.gov.tr, 2006:10). http://www.mevzuat.gov.tr/MevzuatMetin/1.5.2863.pdf (last accessed: 02.07.2017).
} 
cultural tourism into socio-economic development of villages (in Bursa), whereas there is still a gap in research about impacts of touristic activities into the continuity of traditional rural architecture. So, the authors conducted a case study in order to make detailed research and analysis on architectural character and physical condition of rural heritage in selected three villages of Bursa; Misi, Gölyazı and Tirilye. These villages are selected as having various types of natural and cultural values to be conserved and presented for sustainable rural development. Besides, they are commonly subjected to irregular and unplanned touristic activities fulfilling gastronomic and accommodation needs of visitors.

It is aimed to find out the right answers to these questions, as a result of this study;

- Which village has substantial facility to accomodate and feed the tourists?

- Are the existing historic houses and monuments available for being income for the villagers?

- Are there any similarities in between different groups of geography, climate, landscape and ethnicity in these three villages? Is it possible to apply common tourism management plan for three of these villages?

- What are the problems and suggestions to sustain rural heritage during development of the related villages?

- Who are the actors and participants in application of collaborative works done for conservation and reuse of historic buildings and landscapes?
For this purpose of reaching to the answers, initially, a site survey for each villages is required to collect data defining current physical features that includes spatial and functional character to be conserved. Meanwhile, a comprehensive literature review, concerning historical development of their rural heritage, helps us to follow physical changes in their architectural and natural sources. By this, a detailed analysis on values, potentials and problems of related rural settlements was put on a table, in order to make an evaluation on the effects of tourism in their sustainable development. These values can be potential for continuity of rural heritage composed of natural, socio-cultural and recreational tourism reserves, architectural features defining the rural identity are also determined as cultural reserves affecting continuity of rural tourism in these villages.

\section{Cases from Bursa: Misi, Gölyazı and Tirilye}

Bursa has become not only the national but also the international focal point of cultural tourism since having been accepted as one of the UNESCO World Heritage Sites in 2014. The renovation and restoration works have been accelerated since then in order to reuse the dwellings oriented to touristic demands, in historic villages of Bursa. Most of them have become a destination for daily tourism while visitors get the opportunity for gaining experience in knowledge of natural and cultural properties. In this study, the well-known and mostly visited three of these villages are selected as Misi, Gölyazı and Tirilye (Figure 1). Misi is a mountain village along the hillside of Uludağ

Table 1. Physical and social features of Misi, Gölyazı and Tirilye (Authors, 2018)

\begin{tabular}{|c|c|c|c|}
\hline & Misi & GÖLYAZI & TIRILIYE \\
\hline Location & $\begin{array}{l}\text { - Along the hillside of Uludağ Mountain } \\
\text { - } 14 \mathrm{~km} \text { away from Bursa city center }\end{array}$ & $\begin{array}{l}\text { - Near the Uluabat Lake } \\
-21 \mathrm{~km} \text { away from Bursa city center }\end{array}$ & $\begin{array}{l}\text { - Near the Marmara Sea } \\
\text { - } 42 \mathrm{~km} \text { away from Bursa city } \\
\text { center }\end{array}$ \\
\hline Accessibility & $\begin{array}{l}\text {-by public transportation } \\
\text {-by vehicular traffic } \\
\text {-by cycling }\end{array}$ & $\begin{array}{l}\text {-by public transportation } \\
\text {-by vehicular traffic (limited) }\end{array}$ & $\begin{array}{l}\text {-by public transportation } \\
\text {-by vehicular traffic } \\
\text { - by sea route }\end{array}$ \\
\hline $\begin{array}{l}\text { Vehicular } \\
\text { Parking Facilities }\end{array}$ & $\begin{array}{l}\text {-small parking areas } \\
\text {-parking on the roads }\end{array}$ & -large parking area out of the peninsula & $\begin{array}{l}\text { - parking along the seaside } \\
\text { - parking on the roads }\end{array}$ \\
\hline Natural Features & $\begin{array}{l}\text { - Water Element: Nilüfer Stream } \\
\text { - Landscape: within a Valley along } \\
\text { Nilüfer Stream }\end{array}$ & $\begin{array}{l}\text { - Water Element: Apollyon Lake } \\
\text { - Landscape: as a peninsula in Uluabat } \\
\text { Lake }\end{array}$ & $\begin{array}{l}\text { - Water Element: Marmara Sea } \\
\text { - Landscape: as a Sea port near } \\
\text { Marmara Sea }\end{array}$ \\
\hline $\begin{array}{l}\text { Architectural } \\
\text { features }\end{array}$ & $\begin{array}{l}\text { - Traditional houses, forming a texture } \\
\text { - Monumental figures: } \\
\text { * Children's library } \\
\text { *Ethnographic museum } \\
\text { (renovated from historic houses) }\end{array}$ & $\begin{array}{l}\text { - Traditional houses, } \\
\text { spreading apart from each other } \\
\text { - Monumental figures: } \\
\text { * Ancient city walls } \\
\text { * A Cultural Center (renovated from a } \\
\text { Historic Church) } \\
\text { * A monumental plane tree }\end{array}$ & $\begin{array}{l}\text { - Traditional houses, forming a } \\
\text { texture } \\
\text { - Monumental figures: } \\
\text { * Churches and Schools from } \\
\text { Byzantine and Ottoman periods }\end{array}$ \\
\hline $\begin{array}{l}\text { Functional } \\
\text { distribution of } \\
\text { the historic } \\
\text { buildings }\end{array}$ & $\begin{array}{l}\text { - Commercial units lined up along the } \\
\text { Nilüfer Stream } \\
\text { - Houses separated away from the } \\
\text { commercial area }\end{array}$ & $\begin{array}{l}\text { - Commercial units gathered within town } \\
\text { square, and near the lakeside } \\
\text { - Houses separated away from the town } \\
\text { square and gathered within the peninsula } \\
\text { and along the lakeside }\end{array}$ & $\begin{array}{l}\text { - Commercial units lined up along } \\
\text { İskele Street, near the seaside or } \\
\text { the hillside of Çamlitepe } \\
\text { - Houses lined up along İskele } \\
\text { Street and the hillside of Çamlıtepe }\end{array}$ \\
\hline $\begin{array}{l}\text { Cultural tourism } \\
\text { facilities }\end{array}$ & $\begin{array}{l}\text { - Gastronomy } \\
\text { - Handicraft } \\
\text { - Alternative sport activities (trekking, } \\
\text { cycling) } \\
\text { - Pleasure trip travel }\end{array}$ & $\begin{array}{l}\text { - Gastronomy } \\
\text { - Handicraft } \\
\text { - Picturesque scenes for TV serials } \\
\text {-Photographic activities }\end{array}$ & $\begin{array}{l}\text { - Gastronomy } \\
\text { - Handicraft } \\
\text { - Picturesque scenes for TV serials } \\
\text { - Photographic activities }\end{array}$ \\
\hline
\end{tabular}


(Great) Mountain (Figure 2); Gölyazı is a peninsula village by the Shore of Uluabat Lake (Figure 3); and Tirilye is a coastal village near Marmara Sea (Figure 4).

Being located at the west part of Bursa, Misi and Gölyazı are under the responsibility of Nilüfer Municipality, and Tirilye is administrated by Mudanya Muncipality. While these three villages share similarities in physical and cultural features, they differ from each other in terms of natural elements and architectural features (Table 1). They are famous for their natural beauty and vernacular architecture while serving the citizens of Bursa by providing entertainment areas for their leisure time. Hence, the effects of touristic facilities are mostly like each other since the components of their rural heritage is common.

Misi (Gümüsstepe) is a rural area having historical background of approximately two thousand years. In addition to sericulture, its source of income is known as the production of muscadine and molasses from grapes, which currently provides social sustainability. Due to its optimal topography for trekking and cycling, it has also become an essential place for extreme sports. There is a caravan camping area and a restaurant outside of the village that are managed by the Municipality. Besides, this village includes different types of natural elements, such as fruit tree, and plane tree grown along Nilüfer Stream passing through this rural area (Figure 5).

The buildings composing the rural architectural heritage in this village were listed as pieces of urban site to be conserved together with their environmental landscape, in 1989 (Kültür Portalı, 2019). While preparing plans and projects to conserve this heritage, most of the dwellings have been renovated in facade rehabilitation applications (Figure 6). Accordingly, the ones having façade along town square of Misi were restored, whereas the others that are located within the centre of this village are still in ruin due to desolation and dilapidation. The restored ones are mostly reused for leisure or gastronomical needs, possibly for those visiting the village in terms of cultural tourism. For instance, two of the traditional houses, located close to the commercial center of the town, were restored and re-functioned as a "Children's Library" and an "Ethnographic Museum", which are also being used for literary meetings (Figure 7). However, improper and unconscious applications still exist due to similar kind of repairs and restorations, which results in continual problems for the traditional architectural character of this village.

On the other hand, there is an annual organization, named as "Misi Local Tastes Festival (Misi Yerel Lezzetler Senliğt)", improving local gastronomical activities as a part of cultural tourism. Moreover, there is a cooperation, named as "Misian Women Culture and Cooperate Association", responsible for providing public awareness in the cultural heritage in this village by introducing and marketing the handmade products of the women villagers of Misi.

Gölyazı (Apolyont) is a small peninsula protruding into Uluabat (Apollonia) Lake and being connected to the land with a bridge. The village includes various types of immovable cultural properties, such as archaeological remains of Romanian walls, a historic church and a monumental 750 years-old plane tree (Ağlayan Cınar). Despite having lost the traditional character on their facades, dwellings mostly constructed in the 19th century also exist (Figure 8).

Its topographical and natural qualities are so essential to be conserved since it hosts various types of birds, such as the white stork (Figure 9). However, there still is not any conservation plan attempts to survive both architectural and natural values as the parts of its rural heritage. Besides, only some selected dwellings, having a facade to the village's square, have been repaired and renovated within the concept of a street rehabilitation project. However, the ones located inside the village need to be repaired immediately since they have been subjected to various improper use after being abandoned by the owners.

The restoration and renovation activities have been accelerated for a few years in Gölyazı. Dilapidated archaeological remains and ruins of ancient walls surrounding the village are still standing. Archaeological excavations of Necropolis including Sacred Place were completed in 2017, and projected to be an 'Archaeopark' in 2019 (Nilüfer Municipality, 2019c). Besides, Nilüfer Municipality conducted the restoration of St. Panteleimon Church and re-functioned it as a Cultural Center. The traditional house near the church was renovated as a "Writer House" and a historical Turkish bath was also restored and refunctioned as museum and café. However, the remains still need to be repaired and preserved since there is not any conservation decision concerning their stability, whereas even the 
buildings attached to these remains are being rehabilitated (Figure 10).

The villagers are mostly fisher folk, who used to get their income from fishery and basketry as in related with the lake. They recently preferred to change the use of ground floors of their dwellings in order to respond to the commercial demands of cultural tourism. Such kind of functional transformation in spatial characteristics of historic dwellings reveals the negative effects of cultural tourism into authenticity of its architectural features. On the other hand, economic profit of the locals living in this village is still inadequate for a comfortable living due to the irreversible changes in fishing on the lake, which has been subjected to dirtiness and ecological problems as a result of undesirable behaviours of the tourists.

Tirilye (Zeytinbağ ), one of the towns of Mudanya town at the North Seaside of Bursa, is a historical settlement dating back to the Roman Period. Having hosted various types of nations, such as the Romans, Byzantians, and Ottomans, this village has a multi-cultural and multi-religious cultural heritage. In addition to the monumental buildings ${ }^{18}$, four historic fountains, a Roman cemetery, olive oil factory and small workshops exist as a part of local industrial heritage (Figure 11). Moreover, mostly the vernacular architecture and urban pattern that is dated to the Ottoman period are potential to make cultural tourism attractive. Besides, Tirilye has natural assets such as a natural port, olive trees and a pine forest, to be preserved and sustained. The sales of olive oil from these olive trees is one of the essential profits for economical sustainability of the villagers. Along with these olive oil producing factories being economically significant, they also exhibit architectural characteristics of the industrial heritage.

In addition to its architectural heritage, people prefer to visit Tirilye because of its natural beauty and active gastronomical facilities. On account of its topographical conditions, the dwellings built along the seaside are restored and their ground floors are mostly used for new commercial demands, such as fish restaurants and cafes, similar to Gölyazı. This might prevent perceptibility of historical townscape of its vernacular architecture, due to the sheets attached to the facades (Figure 12). On the other hand, the port was enlarged by infilling the seaside, in order to be used as a car park and to respond to the traffic density caused by touristic visits. This, however, is interfering with the pedestrians' access to the beach, where is having one of the viewpoints for taking photographs of this valuable natural landscape (Figure 13).

Besides, this seaside village is hosting much more touristic activities for the public as it is aware of its cultural heritage. In addition to festivals and seminars, it is able to organize sportive activities, such as trekking and mountain climbing, to offer alternative tourism activities for the youth travellers. Furthermore, its cultural heritage is at the center of attraction since many series of TV dramas and documentaries have been made in Tirilye.

\section{Discussion on Findings}

Public participation into the process of heritage conservation, which is significant for sustainability of its identity and authenticity, is also active in this village. For instance, Mudanya Municipality has arranged a seminar in 2018, in order to give information and get local people's opinion about the new function for Taş Mektep in Tirilye. Consequently, it was decided to be used as a cultural and education center. Moreover, the Ottoman Bath was also restored by the Municipality whereas it has not been re-functioned yet.

This part of the article is composed of 'results', including evaluation of values, potentials and problems of the case studies, together with 'recommendations' (Table 2), in order to define strategies on sustainability of architectural and natural heritage in Misi, Gölyazı, and Tirilye villages.

\footnotetext{
${ }^{18}$ These historical monuments are; Taş Mektep (Stone School / Old Clergy School), Aya Yani Manastırl (Aya Yani Monastery), Fatih Mosque (St. Stephanos Church), Kemerli Kilise (Panagia Pantobasillissa Church), and an Ottoman Bath
} 
Table 2. Evaluation and Recommendations (Authors, 2018)

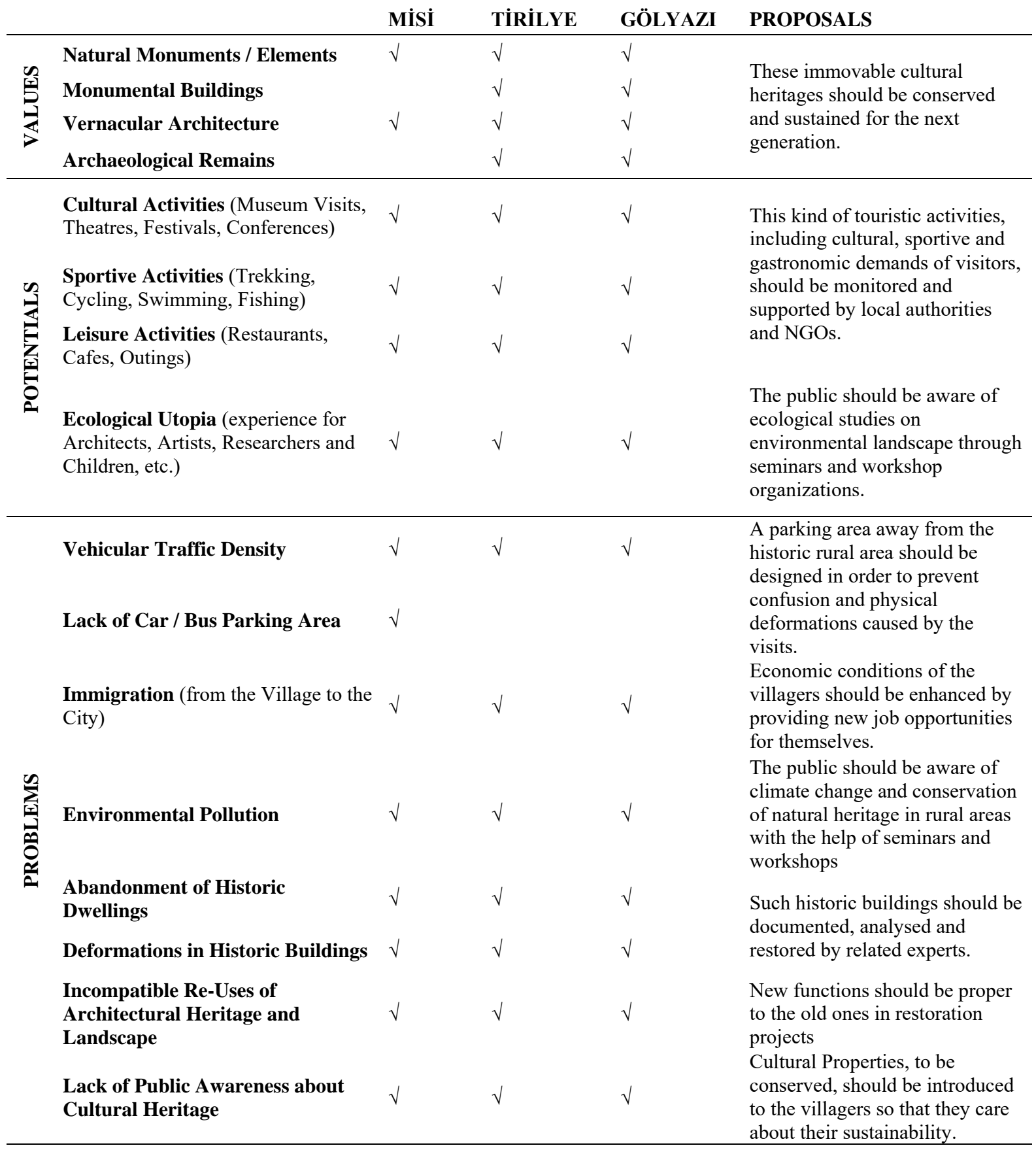

Source: Authors 


\section{Results}

The traditional character of vernacular architecture and natural water features passing through are the common qualities of these three villages to be conserved as cultural heritage. Despite of having various types of cultural properties, the architectural style and construction technique of dwellings and monumental buildings reveal the common points in traditional texture of these rural areas. Accordingly, two-storey height and timber-framed buildings are lined up along narrow streets while a mosque, a natural street element (mostly a plane tree) and surrounding small shops are the major components forming small squares that also define the village's centre.

The number of villagers, who want to get income from rural financial activities such as fishing and agriculture, decreases every passing day in these rural settlements. As Çakmakçı (2016) claims, economic contribution of the tourism might lead labor transformation, while the villagers prefer to set up small businesses on their agricultural land or to sell the land to large tourism enterprices for financial benefit and welfare. This is also a threat for the conservation of rural architectural heritage, since the inner spaces of historic houses are changed as a result of renovation for new commercial uses. For instance, many of the dwellings are restored to be used as boutique hotels and restaurants, which require mostly improper and permanent regulations on both their spatial and structural character, especially in toilets and bathrooms. This critical problem derives from lack of consciousness of the public in heritage conservation.

Street rehabilitation projects mostly result in such kind of alterations due to the use of incompatible construction materials and techniques during repair and renovation implementations. Accordingly, the facades are completely renewed in different proportions and styles of architectural elements, which caused a new texture in both vertical and horizontal views (Figure 14). The instruction panels, defined as contemporary additions attached to the facades, prevent perception of colourfulness and variety in historic townscape. This results in monotype facades, whereas the vernacular architecture has similar, and sometimes same, character to each other. Since it looks like just a surface treatment instead of a comprehensive repair, street rehabilitation studies are currently not enough to conserve integrity and unity of traditional texture. On the other hand, this arouses interest of the visitors, who are willing to see a typical townscape of a historic village settled in a period of time. However, this also causes the variety of related cultural properties to come to an end instead of sustaining the authenticity and the local identity of each villages.

Each of these three historic villages has also the potential to be a case study of architectural and planning design studios, in order to create new architectural forms within traditional texture and to propose new functions for existing historic buildings. For instance, Tirilye was handled by the students from architecture department of Yildız Technical University, within the curriculum of the Design Studio 4, in order to make a research on new forms and concepts on an existed historical area within the village (Sagdic et al. 2015).

\section{Recommendations}

In this part, basic principles described in the Charter of International Cultural Tourism (ICOMOS, 1999) were used to find out necessities and benefits in sustainability of rural heritage in Misi, Tirilye and Gölyazı villages.

\section{Tourism and conservation activities should provide equitable economic, social and cultural benefits to the villagers.}

Rural tourism can enhance livelihood source for the villagers, if the earnings that are gained from the marketting of local sources are completely and equally shared in between related local public. As exemplified by ‘\%100 Misia Project' (Güney et al., 2016), new social development projects should be prepared and financially supported by the Government Institutions, in order to solve employment problem and to make each production a trademark for sustainable development in the related villages of Bursa. Besides, rehabilitation of natural deserves, such as lake and river, is also required for sustainability in ecotourism activities.

Vehicular traffic and parking problems, appeared by increasing touristic visits into the villages, should be solved immediately and harmlessly in order to provide pedestrian safety and heritage conservation among the villagers. Traffic density might be taken under control by making public transportation prevalent and putting parking areas away from the towns' historic square. Such kind of precaution protects historical buildings from physical damages caused by air pollution and the vibration of vehicles. This was applied in Gölyazı village a few years ago, which interfered with the traffic piling up in the center due to the touristic visits (Figure 15). 
The visitors (tourists) should be informed about rural heritage and be experienced about conservation of local sources during deliberative touristic activities.

The historic townscape of narrow streets and the local lifestlye in the villages have been potential for TV dramas and the documentary movies, which increases popularity of the rural heritage and knowledge of the tourists even before coming to visits. Moreover, the cultural routes might be a potential for the visitors to meet and respect with the nature around the villages. The basic principles of these cultural routes should be concerning the essence of the walking, experiencing the nature and respecting to the rural culture and history.

Different forms of touristic activities improve the use of local landscape by the villagers and provide accessibility to the rural heritage by the visitors. According to 'the inside-out approach' (Zhang et al., 2006), the local community could follow its growth principle while tourists come in mostly to enjoy and to learn from the local wisdom.

A sustainable management plan on conservation of architectural values should be in relation between heritage and tourism.

Requirements for an integral and sharing management plan in multi-stakeholder are defined as;

- $\quad$ carrying architectural, archaeological, natural and humanistic values of releted rural area, while preserving it from negative impacts of visitor density

- considering demands of different local institutions and groups about conservation of cultural properties

- correlating the partnership in between local people, NGOs, environmentalists and managers

- supervising the security and the quality of visitors' life while providing opportunities to them for accessing, experiencing and informing cultural heritage

- defining and decreasing the threats, such as congestion, traffic density, and destruction on built environment, for sustainable rural tourism

- collaborating financial contribution of tourism companies and private contractors into a useful management plan,

- adopting into the potential of tourism about benefits for local public, rural architectural heritage and visitors.

Loss of authenticity, appeared due to massive changes in architectural features of these three villages, should not be normalized and underestimated because cultural heritage and nature-based tourism need to be integrated with daily modern life activities in respect to their continuity. In order to investigate originality of rural heritage, an inventory study that contains natural, historical and cultural values in these villages should be prepared. Afterwards, a holistic approach should be adopted for ecological planning principles by using building bylaws. This would work on preparation of rural design, architectural design and restoration projects to be applied in traditional rural settlements.

According to Çelikyay (2016), rural design strategies should be based on culture and art dimensions for the use of public spaces for visual quality and ergonomic street elements for pedestrians. Moreover, reconstruction of public squares and townscape of narrow streets should be applied together with design of vegetation and green spaces suitable for rural ecology. When we highlight the requirements for architectural design, typological studies defining architectural styles including original facades and sillhouttes are essential to guide what should be done for proper restoration and restitution studies on historic buildings.

Hence, these three villages have values and potentials in terms of leisure, farm, health and religion tourism along with substantial accomodation facilities. The abandoned historic factories in Tirilye can be restored and reused for serving local organic farming products (oil production), which would be a potential to gain economic profit for the villagers. Moreover, the historic dwellings, having view of Apolliont Lake in Gölyazı and Nilüfer River in Misi, should also be rehabilitated for use of leisure accomodation, gastronomic places and navigation point of natural Vista.

The tendency of using the original building materials produced with low energy consumption and respect to the environmental features should be major principles of these projects. Hence, traditional (earthen and stone) construction materials should be investigated and reproduced within the context of a Scientific Project, directing to restoration implementations. However, the inhabitants prefer to use contemporary materials like reinforced concrete and concrete briquettes instead of traditional ones. Hence, the principles on new additions and infill within historic rural areas should be restrict, during application process that is composed of three stages (Acun Özgünler et al. 2018) as; 
1. in situ observation,

2. searching for original materials in laboratory tests

3. improving new materials for ecological additives

Shortly, it is essential to specify how to preserve and renew architectural and spatial elements of rural heritage in their own memorial spaces.

Public (the villagers) participation into planning and implementing process is essential for sustainability in rural development.

The villagers should get financial profit from touristic organizations, such as festivals, by selling handmade products, renting rooms of their houses for accomodation or feeding the visitors in ground floor of their houses that have also open-air spaces, named as the yard (avlu). However, public awareness on financial profit from tourism is accepted as not only potentials and profits but also threats for ecological and sustainable tourism. Environmental pollution might appear due to the lack of consciousness on use of natural sources in touristic places, which is a problem to be solved. According to the analysis, water pollution, dilapidation and traffic density are the basic problems of recreational areas.

On the other hand, local authorities should take responsibility for organization of social and educative activities ${ }^{19}$ (ICOMOS, 2008), such as conferences, panels, workshops, lectures and multimedia applications, which might enhance public awareness in understanding the importance of ecological characteristic of historic buildings, while providing sustainability of rural identity. This requires monitoring and educating the public to be aware of climate change and to think about what should be done to stop deformation of natural heritage in rural areas. Hence, villagers would participate in works for sustainability of cultural and natural character of the rural landscape, rather than focusing on short-term benefits from tourism. That kind of actions should be done in a collective work between university, nongovernmental organizations, municipality, governorship and Ministry of Culture and Tourism, along with local residents' perception and participation. Therefore, cooperation between local people and all related stakeholders should be encouraged to ensure participatory management of rural architectural heritage for a sustainable future.
Tourism promotion programmes should enhance conservation status of natural and architectural heritage, while encouraging interest of visitors into the local sources.

Substantial infrastructural facilities are required in the form of accommodation, and transportation. All ranges of hotels, motels and guest houses together with lakes, river valleys, and national parks should be easily accessed and rehabilitated. The functional continuity of historic buildings and landscape in these villages is required for proper restoration implementations, while historic dwellings should mostly be reused for residential and agricultural functions. The restoration and rehabilitation projects should not just serve to touristic interests, but also to the casual requirements of the villagers. More importantly, these projects should be in relation with the principles of a management plan.

In order to take advantage of cultural heritage, it should be valorised in various forms such as conservation, rehabilitation and restoration while providing interfaces for human access and commercializing with fair trade principles. However, built up heritage and natural sources are mostly unique and not familiar with replacement and market for touristic demands so easily. Hence, a 'Cultural Tourism Development Model' is required for sustainable rural development under the pressure of tourism. By this, the participants can also get into wide communication and control of an integrated and holistic structure, while natural and cultural values forming the identity are carried to the future generations. The stages of this model should be composed of;

1. Collecting the data by an inventory study

2. Making SWOT analysis and evaluating the current potential

3. Planning and organizing a program

4. Creating an effective image as the model

5. Applying the plan

6. Monitoring and Following the Process after application

The scholars (Beyhan et al. 2005; Bahçe 2009; Gülhan 2016) studied to propose such kind of model by evaluating the input for sustainable tourism under different dimensions, including scale, time, content, process and behaviour. Moreover, a participatory governance model named as 'Cumalıkızık Collaboration Project' was also studied (Taş et al. 2009), in order to achieve the conservation and revitalization of the historical

${ }^{19}$ from " the ICOMOS Charter for the Interpretation and Presentation of Cultural Heritage Sites", which was ratified by the 16th 
built-environment together with sustainable development of the village. Accordingly, similar principles might be accepted for sustainable rural development plan required for continuity of architectural and natural heritage of other three villages in Bursa.

\section{Conclusion}

This article exemplifies the impacts of tourism on conservation and continuation of rural architectural heritage in three villages of Bursa: Misi-Gölyazı and Tirilye. According to the analysis, it is clear that increasing demand of tourism may cause physical transformation in spatial and structural features of historic buildings. Besides, the alteration of rural lifestyle demonstrates the pressure of touristic activities due to its gradually increasing density and profit for economical demands.

The general problem is the consumption of architectural and natural features, composing the rural heritage, as the major sources for touristic benefits, which mostly results in loss of identity, authenticity and homogeneity of rural architectural heritage, within its landscape. That risk of continuous transformation and depletion might be the end of rural culture, while causing permanent changes in traditional proportions and construction elements forming the dwellings and monumental buildings, aimed to be conserved as architectural heritage in this villages.

Instead of that kind of problems, touristic actions might become potential for promotion and presentation of the products made by the villagers, in renovated buildings having facade to the town's central square. For the success in providing sustainability of rural architectural heritage, collaborative and public participated studies are required to be applied, within the monitoring of local institutions having sensitive approaches in conservation of cultural properties in related villages. Participation of local authorities into the development of cultural tourism is also significant for a sustainable conservation (Guidelines for Sustainable Cultural Tourism in Historic Towns and Cities), since they cooperate with related stakeholders in common responsibilities and obligations. In case of Bursa, the municipalities of Nilüfer and Mudanya have started to organize social gatherings by the help of festivals and workshops, making the public to be informed about heritage while providing also a gain for the continuity of the rural lifestyle in Bursa.
More importantly, the results of physical analysis and assessment in this study might be a base for prospective researches concerning the same issue in similar kind of rural settlements. Besides, the model of management plan, which was proposed previously, should be a good example for sustainable rural development of other villages having similar natural and cultural characteristic to be conserved and visited.

Shortly, there are three major proposals as the guide for success in future studies:

proposal 1: An interdisciplinary approach on management of cultural tourism is essential for both conservation and development of rural heritage (Kaminski et al. 2014). Hence, a collective study should be required while including contributions from well-known academic and practitioners working in museum management, urban tourism, heritage management, economics, technology, landscape, architecture, history, business, geology and geography.

proposal 2: Tourism destinations, concerning cultural routes, touristic tours and accommodation issue, should be developed in a sustainable manner. This happens due to poor management causing the loss of cultural integrity and ecosystems of the villages. Hence, this management system is required to highlight afford of the individual stakeholders, in order to establish better co-operation and co-ordination of rural tourism activities.

proposal 3: The village houses should be restored in compatible new construction technique with traditional texture while having a form based on the land. This results in organized spaces that differentiates according to climatic factors together with social and cultural conditions of the users. Hence, they should be climatically responsive even after their restorations, not only to respect traditional values but also to take advantage of thier essential ecological and financial benefits for a sustainable development.

Consequently, this study is unique as it bridges the gap in knowledge of tourism effects on sustainability of architectural heritage in different three villages in Bursa, while investigating similarities and variances in providing economical profit into local life in rural areas. More importantly, the theoretical framework utilised in this study could be updated and possibly used in the future context of a longitudinal study. 


\section{References}

Acun Özgünler, S.; Özgünler, M. (2018), “A Research on Sustainability of Traditional Buildings by $\mathrm{Re}^{-}$ Using The Local Earthen Materials", Gazi University Journal of Science, GU J Sci 31(4): 985-994 (2018), pp. 985-994.

Aslam, M.S.; Awang, K.W. (2015), "Enterprising Rural Tourism for Sustainable Rural Development in Sri Lanka", International Journal of Economics and Financial Issues, 5 (Special Issue), pp. 27-33.

Babayev, A. (2016), "Kursal Turizme Kavramsal Yaklaşım, Kırsal Turizmin Önemi ve Etkileri: Türkiye örneği”, [A conceptual Approach in Rural Tourism, Importance and Effects of Rural Tourism], Süleyman Demirel Üniversitesi Sosyal Bilimler Enstitüsü Dergisi, sayı: CIEP Özel Sayısı, pp. 534-543.

Bahçe, A.S. (2009), "Kırsal Gelişimde Kültür (Mirası) Turizmi Modeli”, [Cultural (Heritage) Tourism Model in Rural Development], Dumlupinar Üniversitesi Sosyal Bilimler Dergisi, say1:25, pp.1-12.

Baysal, K., Özgürel, G., Çeken, H. (2016), “Aydın Yöresindeki Yerel Etkinliklerin Kırsal Turizm Açısından Değerlendirilmesi”, [The Evaluation of Rural Tourism in Aydin Region in Terms of the Local Activities], International Jorunal of Social and Economic Sciences, 6 (1), pp. 100-108.

Beceren Öztürk, R., Ispalar Çahantimur, A. (2010), "Valuation of Traditional Turkish Wooden Building Culture in Terms of Ecological and Socio-Cultural Sustainability, Case Study Cumalıkızık / Bursa", World Applied Sciences Journal, 10 (4), pp. 466-471.

Beyhan, S.G., Ünügür, S.M., (2005), "Çağdaş Gereksinmeler Bağlamında Sürdürülebilir Turizm ve Kimlik Modeli”, [Sustainable Tourism and Identity Model in the Context of Contemporary Requirements ], İTÜ Dergisi / a, Mimarlık, Planlama, Tasarım, cilt:4, sayı:2, pp. 79-87.

Boz, M., Eryaman, M.Y., Özkan, Ç., (2014), "Kırsal Kalkınmada Turizmin Önemi: Nusratlı Köyü Örneği”, [The Importance of Tourism in Rural Development: Nusratlı Village Case Study], JED / GKD, no:9:2, pp. 293-308.

Bulut, Z., Yilmaz, H. (2008), "Evaluation of Natural, Cultural and Visual Values in Terms of Alternative Tourism in the Example of Kemaliye (Erzincan / Turkey), International Journal of Natural and Engineering Sciences, 2 (2), pp. 1320 .

Butler, R. and Clark, G. , 1992. "Tourism in rural areas: Canada and United Kingdom". Economy and Society, 2, 166-186.
Çakmakçı, E. (2016), “Turizm Bölgelerindeki Kırsal Alanlarda Emek Dönüşümü: Milas Kırsal Yörelerine Dair Bir Çalışma”, [Transformation of Labor in Rural Areas in the Tourism Regions: A Study on Milas Rural Areas], International Journal of Social and Economic Sciences, 6 (2), pp.16-24.

Çelik, A., Polat Üzümcü, T., Çetin, İ. (2016), "Bursa İli Gölyazı Köyü'nün Açı Hava Rekreasyon Potansiyeli”, [Outdoor Recreation Potential of Gölyazı Village of Bursa Province], International Journal of Social and Economic Sciences, 6 (2), pp. $32-40$.

Çelikyay, S. (2016), "Strategies on Sustainability of Historical and Cultural Heritage in Amasra, Turkey", International Journal of Cultural and Social Studies (IntJCSS), Vol. 2 (special issue 1), ISSN: 2458-9381, pp. 104-116.

Çetin, T. (2010), "Cumalıkızık Köyünde Kültürel Miras ve Turizm Algisı", [Perception of Cultural Heritage and Tourism in Cumalıkızık Village], Milli Folklor, yıl 22, sayı 87.

Davardoust, S.; Karahan, F. (2019), "Vernacular Architecture for Sustainable Rural Development: A Case Study of Kaleybar District in Iran", Atatürk Üniversitesi Mimarlık ve Tasarım Fakültesi, ATA Planlama ve Tasarım Dergisi, cilt: 3, sayı: 1 , pp. 59-68.

Denk, E., Mil, B. (2016), "Erzurum Oltu İlçesinin Kırsal Turizm Potansiyeli ve Yerel Halkın Turizm Algılamaları", [Rural Tourism Potential of Erzurum-Oltu: Perception of Local Residents], International Journal of Social and Economic Sciences, 6 (2), pp.7-15.

Dinçer, Y., Dinçer, İ. 2005, "Historical Heritage Conservation - Restoration in Small Towns and Question of Rural Gentrification in Turkey", Section III:Evolving Townscape and Lanscapes within Their Settings: Managing Dynamic Change, 15th ICOMOS General Assembly and International Symposium, 17 - 21 October 2005, Xi'an, China.

Ertürk, S.A., 2009, "Zeytinbağı (Tirilye) 'nda Turizm Imkanları" [Tourism Opportunities in Zeytinbağ] ], İstanbul Üniversitesi Edebiyat Fakültesi Coğrafya Bölümü, Coğrafya Dergisi, sayı:19, sayfa 1-27, İstanbul.

Fernandes,J., Mateus, R., Bragança, L., Correia da Silva, J.J. (2014), "Portuguese Vernacular Architecture: The Contirbution of Vernacular Materials and Design Approaches for Sustainable Construction”, Architectural Science Review, Vol. 58, Issue 4: Cultural Sustainability: Part A, pp. 324-336.

Gülhan, D., (2016), "Sürdürülebilir Turizm Kapsamında Tarım Endüstrisi ve Zeytinyağı Turizminin Birgi Yerleşiminde Olabilirliği Üzerine Bir 
Değerlendirme", [In the Context of Sustainable Tourism: An Evaluation About the Possibility of the Agri-Industrial Tourism and Oleo-Tourism in Birgi Settlement], Social Sciences (NWSASOS), 11 (2), pp. 116-132.

Güney, D., Göller, V. (2016), "Kırsal Turizm Konusunda Yerel Halkın Yaklaşımının Belirlenmesi: Misi Köyü Örneği” [Determination of Approaches of Local Community in Rural Tourism, Misi Village], Tourism Academic Journal.3 (2), pp.2536 .

Gürdoğan, A., Tetik, S. (2016), "Salihli'nin Kırsal Turizm Potansiyelinin Değerlendirilmesi”, [Rural Tourism Potential Evaluation of Salihli], International Journal of Social and Economic Sciences, 6 (1): pp. 59-68.

Gürer, N. (2003), Kırsal Geleneksel Konut Dokusunun Turizm Bağlamında Değerlendirilmesi, Cumalıkızık Örneği, [The Evaluation of the Rural Traditional Housing Pattern Within the Content of Tourism, Cumalıkızık Case], Master Thesis in Science, Gazi University Institute of Science and Technology, Ankara.

Kaminski, J., Benson, A. M., and Arnold, D. (2014), Contemporary Issues in Cultural Heritage Tourism, Abington and New York, Routledge, ISBN 978-0-203-583368-5.

Karacaoğlu, S., Yolal, M., Birdir, K. (2016), "Toplum Temelli Turizm Projelerinde Katılım ve Paylaşım: Misi Köyü Örneği”, [Participation and Sharing in Community Based Toursim Projects: The Case of Misi Village], Çă Üniversitesi Sosyal Bilimler Dergisi, 13(2), pp. 103-125.

Kocaman, M.; Kocaman, E.M. (2014), "The Importance of Cultural and Gastronomic Tourism in Local Economic Development: Zile Sample”, International Journal of Economics and Financial Issues, vol. 4, no. 4, ISSN:2146-4138, pp.735-744.

Lane, B., Kastenholz, E. (2015), "Rural tourism: the evolution of practice and research approaches towards a new generation concept?", Journal of Sustainable Tourism, 23(8-9):1133-1156.

Liu, A., 2006. "Tourism in rural areas: Kedah, Malaysia”.Tourism Management, 27 (5), 878-889.

Öter, Z., Ünal, E. (2017), "Somut Olmayan Kültürel Mirasın Beypazarı Turizm Destinasyonunda Yerel Ekonomiye Katkıları”, [Contribution of Intangible Cultural Heritage to Local Economy in Beypazarı Tourism Destination], International Journal of Contemporary Toursim Research 1, pp. 26-37.

Özorhon, G., Özorhon, İ.F. (2014), "Learning from Mardin and Cumalıkızık: Turkish Vernacular Architecture in the Context of Sustainability", Arts, 3, ISSN 2076-0752, pp. 175-189.
Pirselimoğlu Batman, Z., Çelik Çanga, A., Sökmen, T. (2019), "Kültürel Peyzajların Kırsal Turizm ile Kullanım İlişkisinin Değerlendirilmesi: Cumalıkızık-Bursa Örneği”, [Evaluation of Relationship of the Cultural Landscapes and Rural Tourism Use: Cumalıkızık-Bursa Example], Journal of Bartın Faculty of Forestry, 21 (1), pp. 1-13.

Robinson, J. (1989). Architecture as a Medium for Culture: Public Institution and Private House. S. Low and E. Chambers (Ed.s), Housing, Culture and Design, a Comparative Perspective. Philadelphia: University of Pennsylvania Press.

Sagdic, Z., Değirmenci, A. (2015), "Searching of the Concept in Tirilye: an Architectural Design Studio", Procedia - Social and Behavioral Sciences, 174, pp. 977-983.

Sharma, S., Sharma, P. (2013), "Traditional and Vernacular Buildings are Ecological Senstive, Climate Responsive Designs-Study of Himachal Pradesh", International Journal of Chemical, Environmental \& Biological Sciences (IJCEBS), vol 1, issue 4, pp. 605-609.

Soykan, F. (2003), "Kırsal Turim ve Türkiye Turizmi için Önemi”, [Rural Toursim and Tirkiye Turizmi için Önemi], Aegean Geographical Journal, 12, pp.111.

Şengül, S., Bayhan, İ. (2018), “Turizm Destinasyonların Sürdürülebilir Gelişim: Göynük Yerel Turizm Paydaşları Üzerine Bir Araştırma”, [Sustainable Development in Tourism Destinations: Research on Göynük Local Tourism Stakeholders], Journal of Travel and Hospitality Management, 15 (3), pp. 489-505.

Taş, M., Taş, N., and Çahantimur, A. (2009), "A Participatory Governance Model for the Sustainable Development of Cumalıkızık, A Heritage Site in Turkey", Environment \& Urbanization, International Institute for Environment and Development (IIED), vol. 21 (1), pp. 161-184.

Tezcan, A.M. (2010). Rethinking Transformation with Tourism: The Case of Izmir-Alaçatı. Master Thesis. Middle East Technical University, The Department Of Urban Policy Planning And Local Governments. Ankara

Uslu, A. and Kiper, T., (2006), "Turizmin Kültürel Miras Üzerine Etkileri: Beypazarı / Ankara Örneğinde Yerel Halkın Farkındalığı" [Effects of Tourism on Cultural Heritage: Public Awareness in Example of Beypazarı: Ankara], Tekirdağ Ziraat Fakültesi Dergisi, sayı 3 (3), Tekirdağ, 305-314.

Uysal Ürey, Z. Ç. (2019), "Sociocultural Role of Architectural Types: Cultural Sustainability in Architecture and the Possibility of Convention", GRID, vol. 2, no. 1. pp. 83-99. 
Wahid, A. (2012), "Adaptive Vernacular Options for Sustainable Architecture", Journal of the International Society for the Study of Vernacular Dettlements, ISVS e-journal, vol.2, no:2, pp.74-87.

Wood, M. E., 2001. "Ecotourism and sustainable development". Industry and Environment, 24 (34), 10-13.

Yu, D. W., Hendrickson, T. and Castillo, A., 1997. "Ecotourism and conservation in Amazonian Peru: Short-term and long-term challenges". Environmental Conservation, 24 (2), 130-138.

Zhang, T. X., Yamamura, T., Fujiki, Y., (2006), "Can Vernacular Buildings Survive With Traditional Life Inside and Tourism Outside?", WIT Transactions on Ecology and the Environment, Vol 97, WIT Press.

Sources for Satellite Images of the Villages: General Directorate of Map [Harita Genel MüdürlüğüHGM] (access date: 20.03.2019)

HGM, 2019a. Satellite Image of Bursa.

https://atlas.harita.gov.tr/\#10.48/40.2899/28.9189,

HGM, 2019b. Satellite Image of Misi.

https://atlas.harita.gov.tr/\#16.35/40.176806/28.968168

HGM, 2019c. Satellite Image of Gölyazı.

https://atlas.harita.gov.tr/\#16.02/40.166066/28.677322.

HGM, 2019d. Satellite Image of Tirilye.

https://atlas.harita.gov.tr/\#15.87/40.391956/28.795852

\section{Online Sources:}

EU Sustainable Tourism Guidelines (2009), Guidelines for Sustainable Cultural Tourism in Historic Towns and Cities.

http://www.historic-towns.org/documents/downloads/ SustainableTourismGuidelines.pdf (Last access: 30.06.2017)

European Rural Heritage Observation Guide (2003), the 13th Session of the CEMAT, 16-17September 2003, Ljubljana.

https://rm.coe.int/16806f7cc2 / (Last access: 03.01.2019)

ICOMOS, 1999. International Cultural Tourism Charter Managing Tourism at Places of Heritage Significance.

https://www.icomos.org/charters/tourism_e.pdf (Last access: 03.01.2019)

ICOMOS, 2008. The ICOMOS Charter for the Interpretation and Presentation of Cultural Heritage Sites.

https://www.icomos.org/images/DOCUMENTS/Charters /interpretation_e.pdf (Last access: 03.01.2019)
ICOMOS, 2011. The Valletta Principles for the Safeguarding and Management of Historic Cities, Towns and Urban Areas.

http://civvih.icomos.org/sites/default/files/Valletta\%20\% 20Principles\%20GA\%202011_CIVVIH_text_EN_ FR_final_20120110_0.pdf (Last access: 03.01.2019)

Kültür Portalı, 2019. "Misi Köyü - Bursa", Türkiye Kültür Portalı web site,

https://www.kulturportali.gov.tr/turkiye/bursa/gezilecek yer/misi-koyu (Last access: 03.01.2019)

Nilüfer Municipality, 2019a. "Misi'ye Bir Ödül Daha", Nilüfer Municipality web site,

http://www.nilufer.bel.tr/haber-5763-

misiye_bir_odul_daha (Last access: 20.02.2019)

Nilüfer Municipality, 2019b. "Nilüfer Belediyesi Gölyazı'nın Geleceğini Yeniden Şekillendiriyor”, Nilüfer Municipality web site,

http://www.nilufer.bel.tr/haber-3699\#prettyPhoto[galeri3866]/0/ (Last access: 03.01.2019)

Nilüfer Municipality, 2019c. “Gölyazı'daki Nekropol ve Kutsal Alan Kazıları Sona Erdi”, Nilüfer Municipality web site,

http://www.nilufer.bel.tr/haber-4800golyazidaki_nekropol_ve_kutsal_alan_kazilari_s ona_erdi\#PopupGoster[popup]/0/ (Last access: 03.01.2019)

WCED [World Commission on Environment and Development], 2019. Report of the World Commission on Environment and Development: Our Common Future (The Brundtland Report).

http://www.un-documents.net/wced-ocf.htm

(Last access: 03.01.2019) 


\section{Jomat}

\section{Figures:}

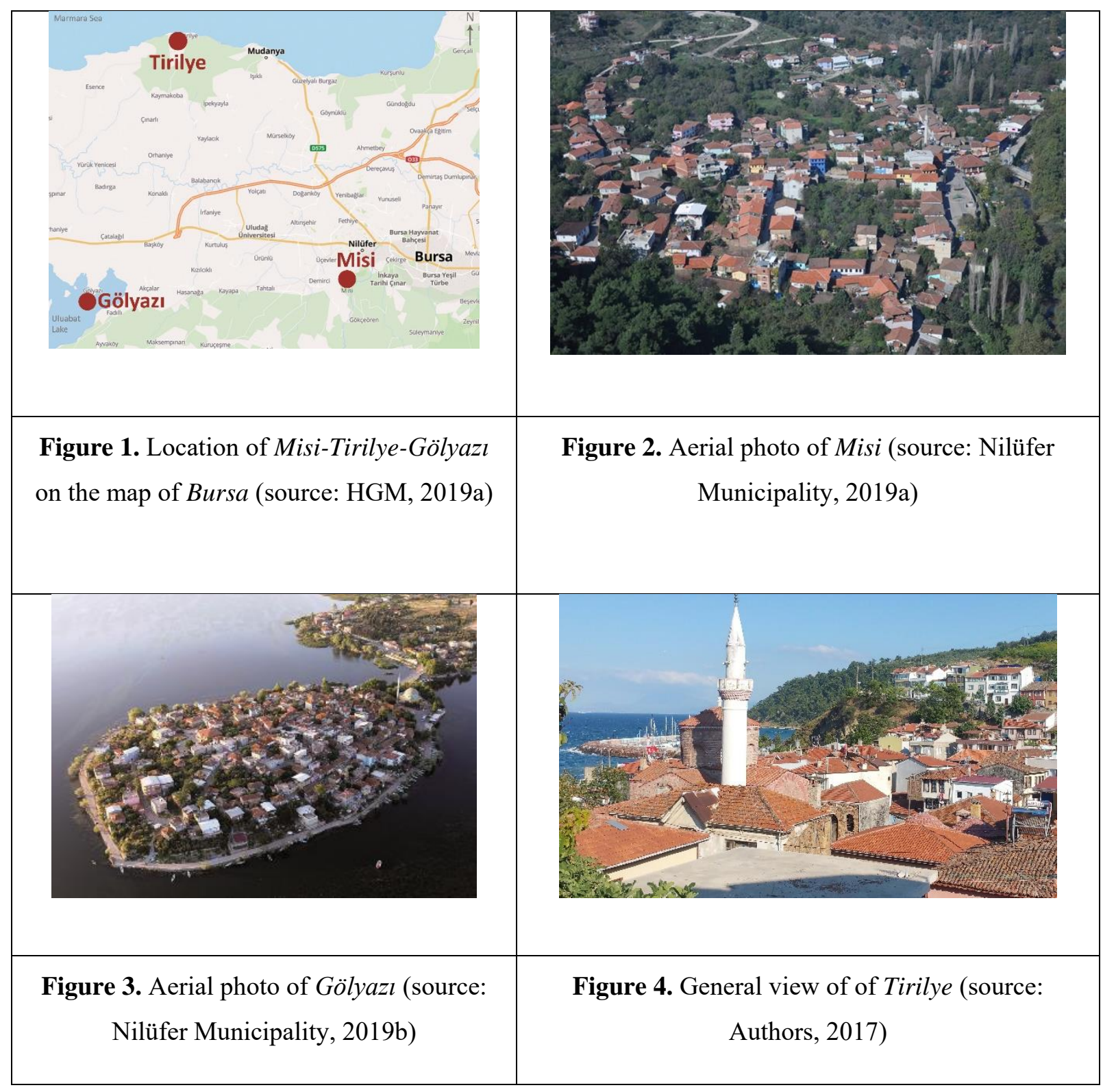



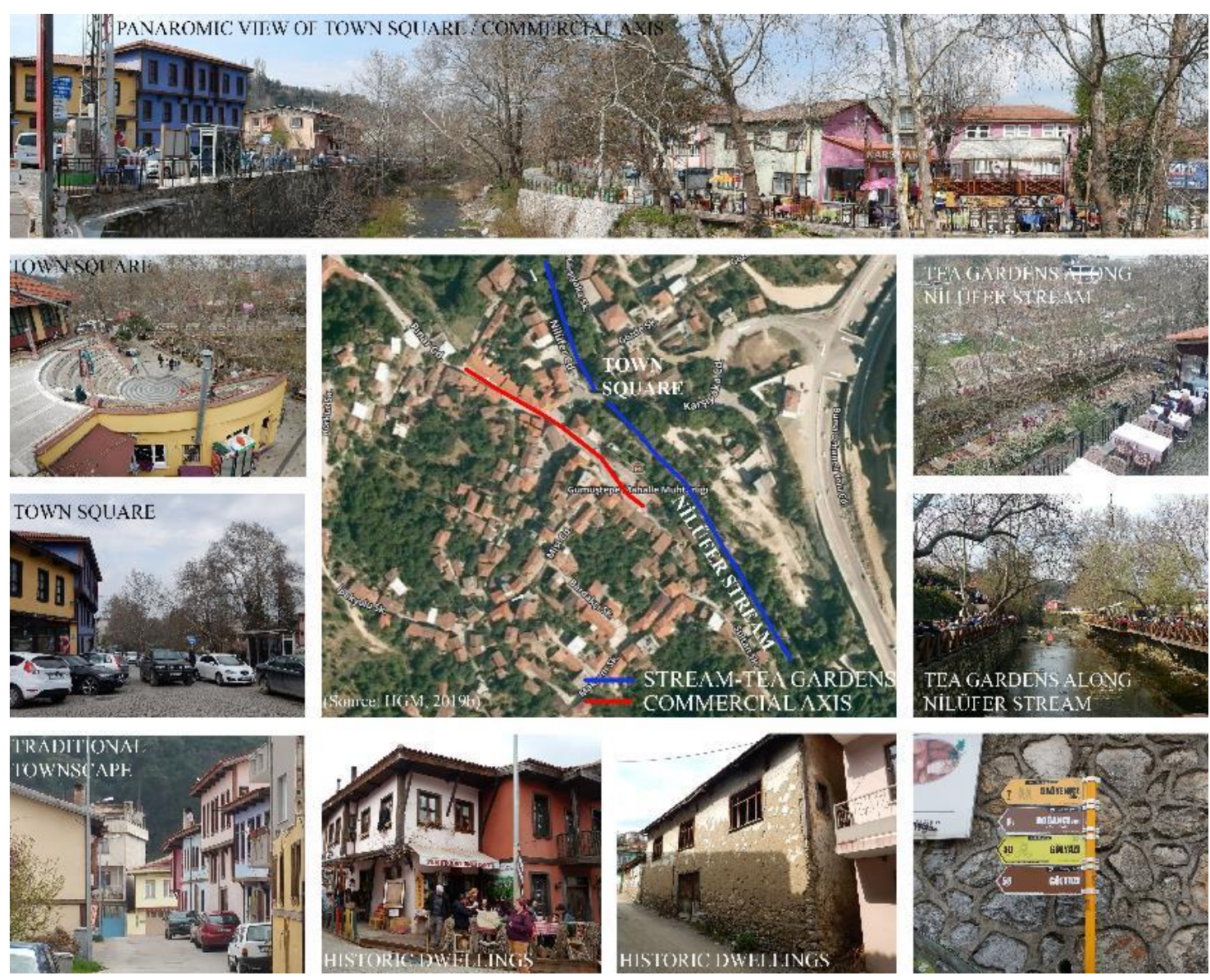

Figure 5. Misi - Aerial photo (source: HGM, 2019b), traditional texture and historic dwellings (source: Authors, 2017)
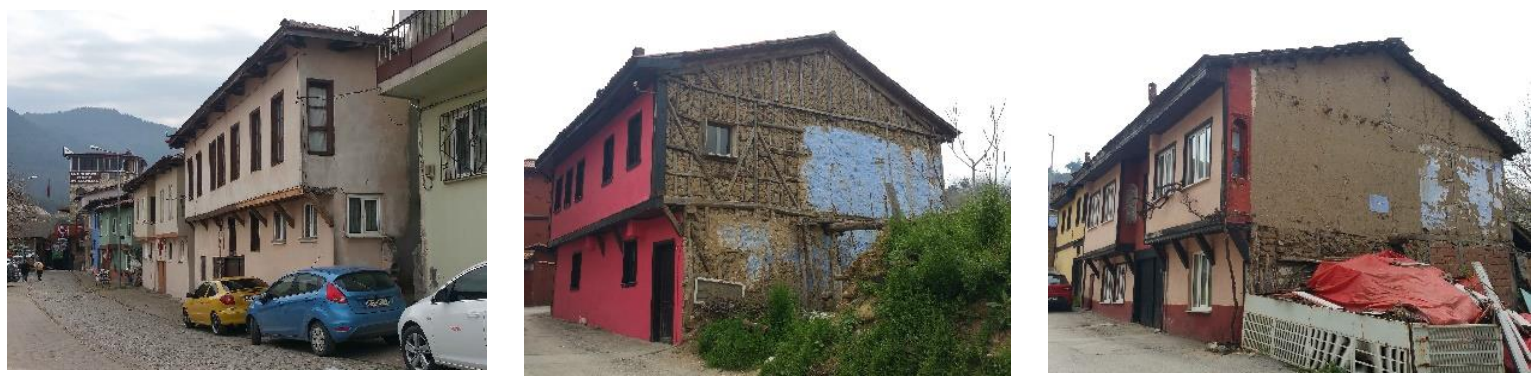

Figure 6. Façade Rehabilitation Applications in Misi (source: Authors, 2017) 

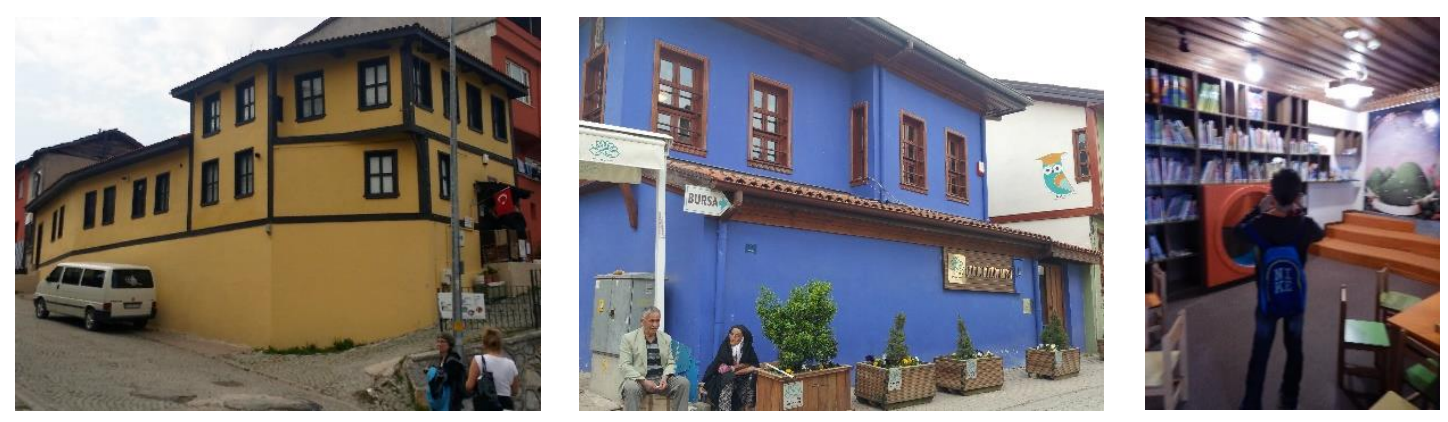

Figure 7. Historic dwellings restored and refunctioned for cultural touristic demands (source: Authors, 2017)
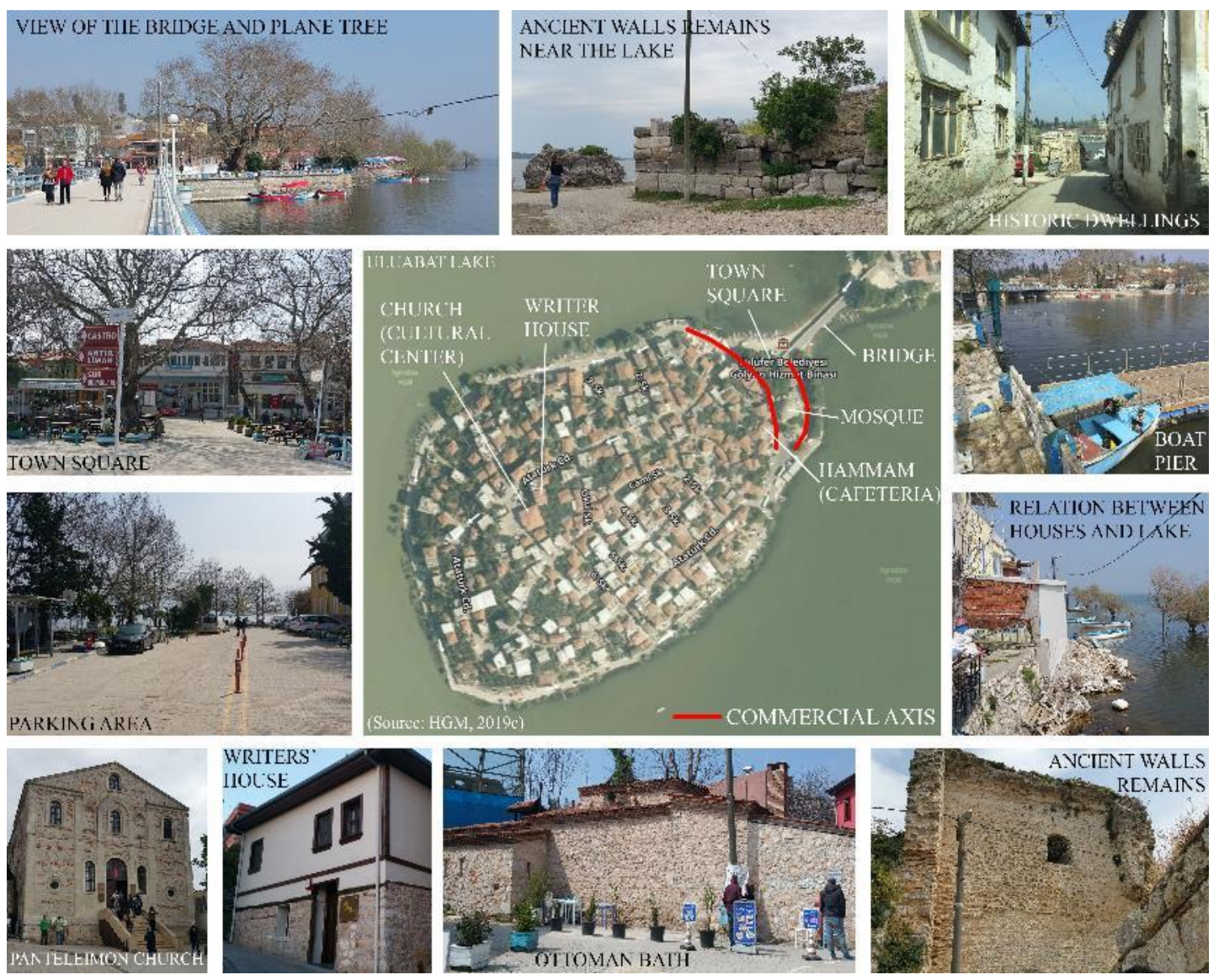

Figure 8. Gölyazı - Aerial photo (source: HGM, 2019c), traditional texture and historic dwellings (source: Authors, 2017) 

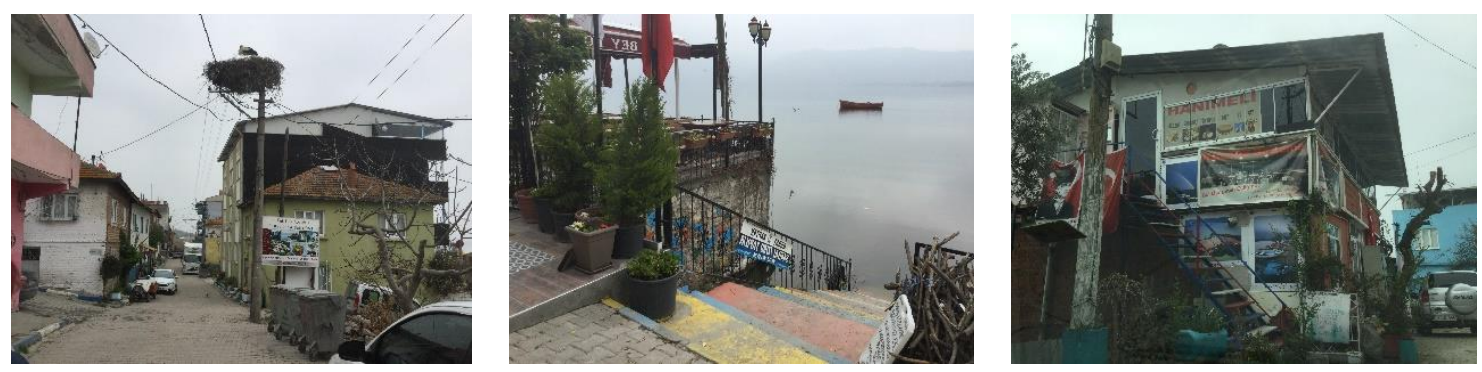

Figure 9. Bad condition of traditional dwellings due to improper use, such as being fish restaurant and café (source: Authors 2017)
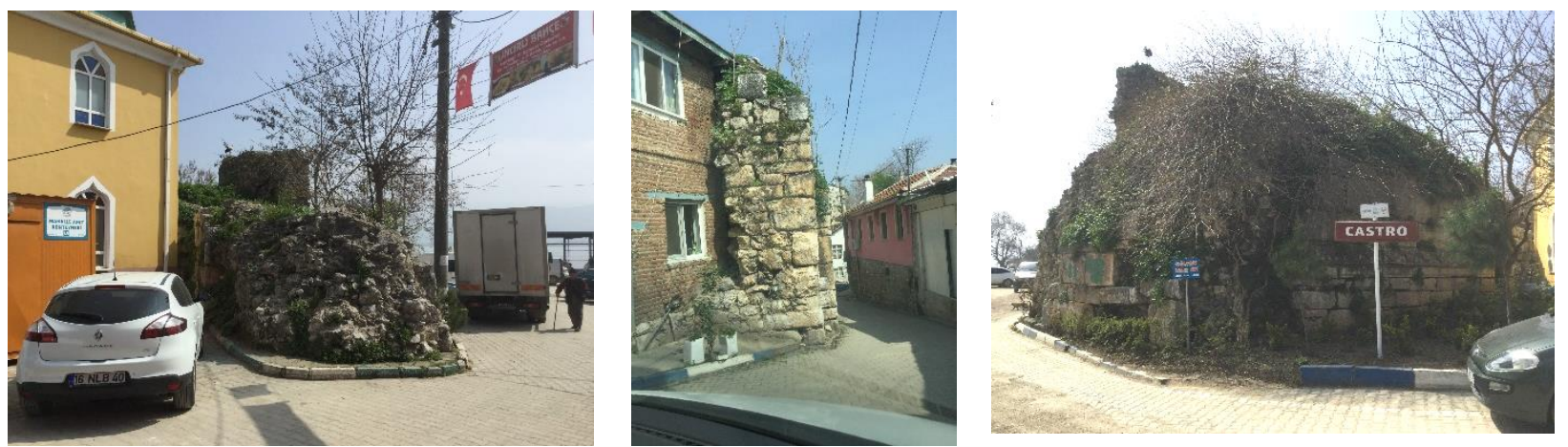

Figure 10. The archaeological remains inside the village that need to be repaired and conserved immediately (source: Authors, 2017) 


\section{Jomat}
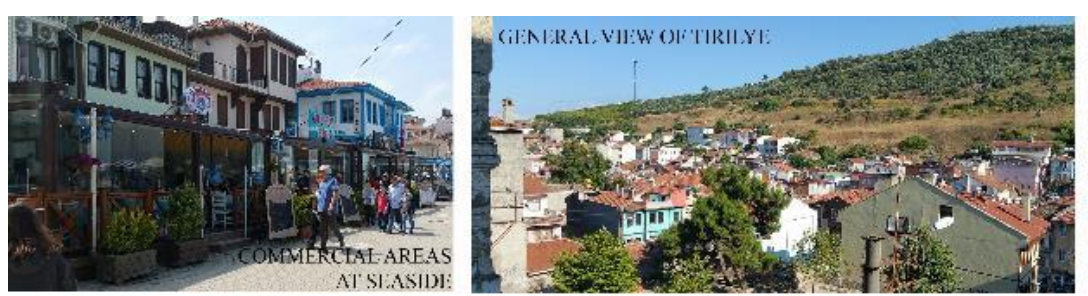

Sermin Çakıcı Alp, Elif Acar Bilgin
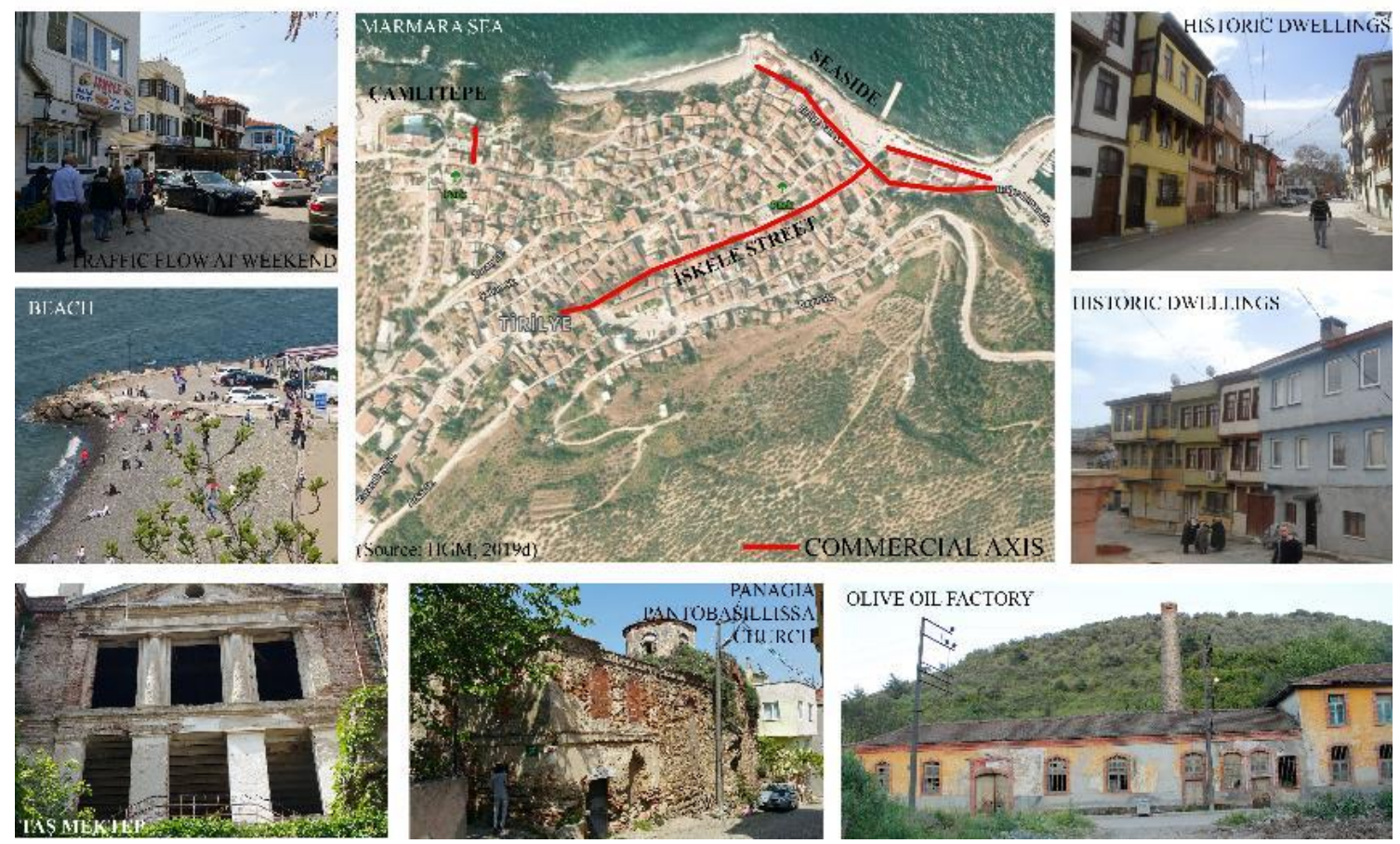

Figure 11. Tirilye - Aerial photo (source: HGM, 2019d), traditional texture and historic dwellings (source: Authors, 2017)
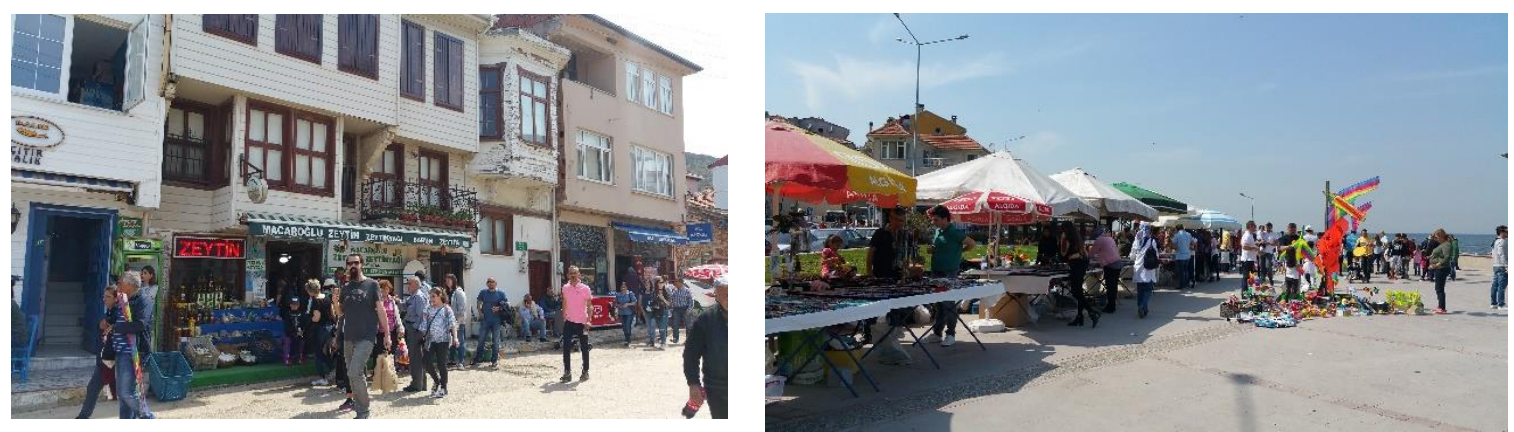

Figure 12. The use of ground floors of dwellings and the seaside for commercial demands (source: Authors, 2017) 

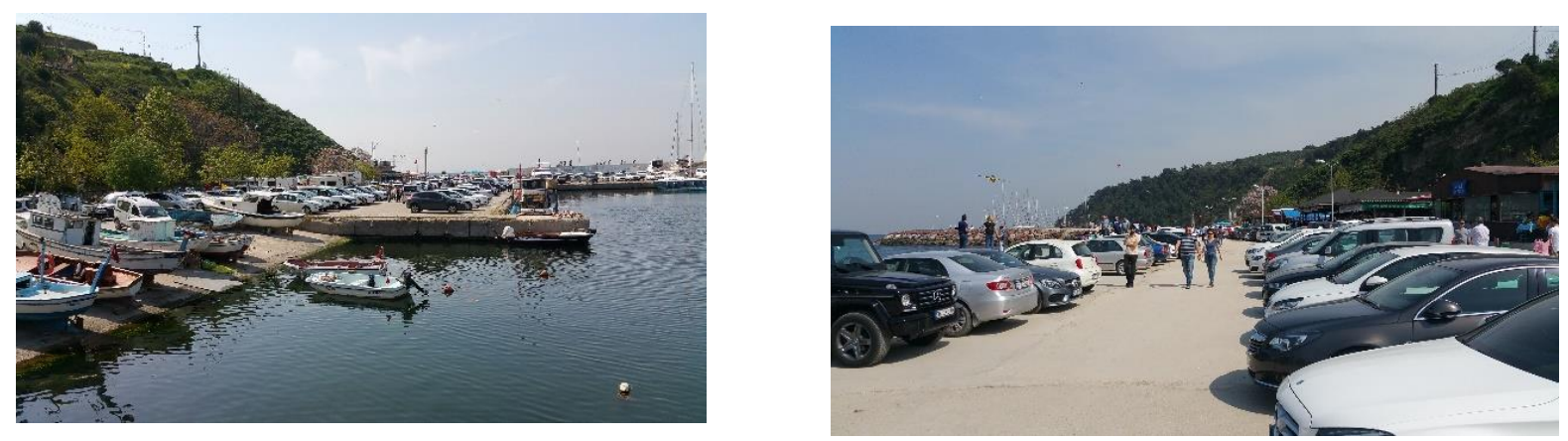

Figure 13. The seaside that is used as parking area in Tirilye (source: Authors, 2017)
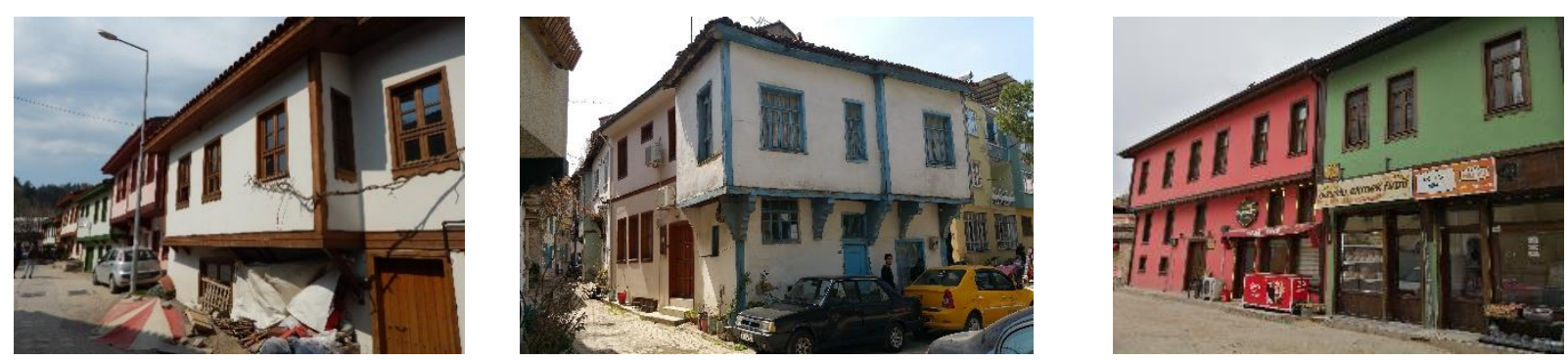

Figure 14. Proportions on Facades of Traditional Dwellings, after Street Rehabilitation Projects; examples from Misi, Tirilye, and Gölyazı (source: Authors, 2017)
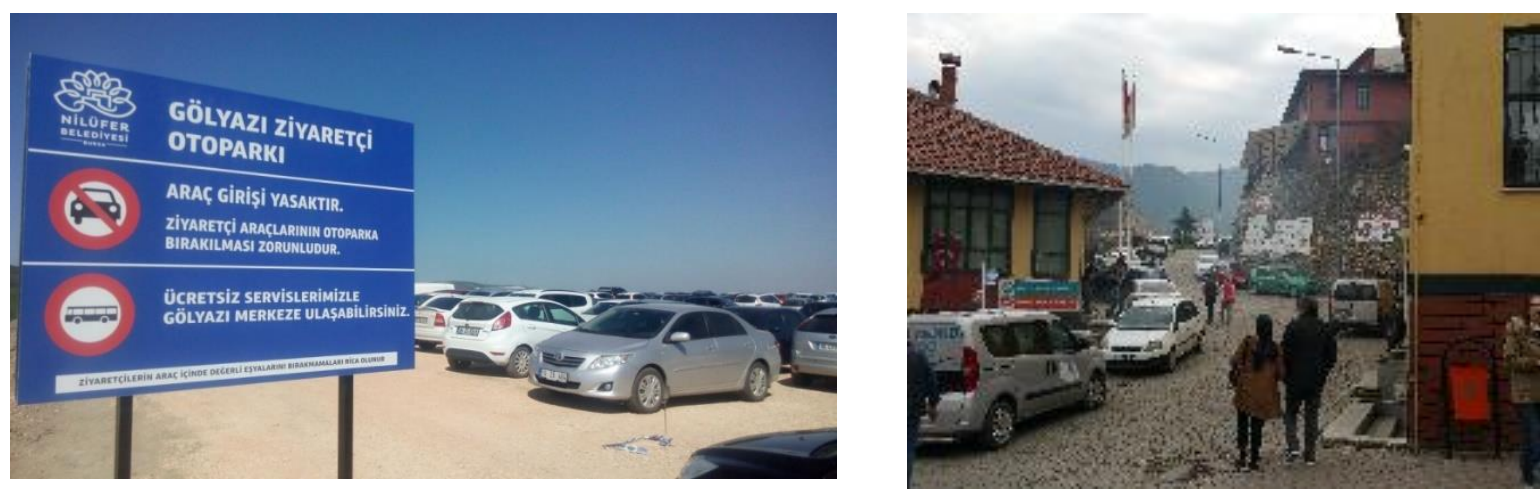

Figure 15. Different solutions for car and bus parking-area in Gölyazı and Misi (source: Authors, 2017) 